\title{
Not Quite A BRAVE NeW WORLD: VICTORIA'S OCCUPATIONAL HEALTH AND SAFETY ACT 2004
}

\author{
K LEE AdAMs*
}

[This article provides a concise overview of the Victoria's new Occupational Health and Safety Act 2004 ("OHSA 2004”). After outlining the Maxwell Report on which much of the OHSA 2004 is based, the article examines the principal legislative provisions of the Act, especially those that differ from the Occupational Health and Safety Act 1985 (Vic) ("1985 Act”). Analysis of the legislation evaluates some positive developments, as well as suggests amendments. Although the OHSA 2004 contains numerous alterations in its scheme as compared to the 1985 Act, these changes are unlikely to usher in a brave new world of occupational health and safety regulation in Victoria.]

\section{INTRODUCTION}

In November 2004, the Victorian Parliament introduced legislation which repealed the nearly twenty-year-old Occupational Health and Safety Act 1985 (Vic) ("1985 Act”) and promulgated a new piece of occupational health and safety legislation, The Occupational Health and Safety Act 2004 (Vic) (“OHSA 2004”). ${ }^{1}$ The OHSA

\footnotetext{
" Lecturer, Deakin Law School. Thanks go to the anonymous referee and editors of the Deakin Law Review for helpful suggestions.

${ }^{1}$ See Victoria, Parliamentary Debates, Legislative Assembly (18 November 2004) 1759 (Hulls, Minister for WorkCover) and id at 1765 (Doyle, opposition leader).
} 
2004 was passed on 17 December 2004 and received royal assent on 21 December 2004. The OHSA 2004 came into effect largely from 1 July 2005, although some provisions will not become effective until 2006. ${ }^{2}$ The changes to Victoria's workplace health and safety law come on the heels of important changes to workers' compensation in Victoria through extensive amendments to the Accident Compensation Act 1985 (Vic) (ACA) both in 2003 and 2004.

The OHSA 2004 was based in large part on an extensive review of the 1985 Act, conducted by Chris Maxwell, QC. ${ }^{3}$ According to the Maxwell Report, the issue of occupational safety and health is "of paramount importance" to Victorians. The Victorian WorkCover Authority (WCA) is the umbrella agency which oversees both Victoria's workers' compensation scheme and its occupational health and safety laws and regulations. The WCA is divided into two primary divisions: WorkSafe (responsible for administering the Occupational Health and Safety Act) and Rehabilitation and Compensation (which administers the workers' compensation regime). The WCA reports that " 29 Victorians died as a result of a workrelated incident”, not including deaths from work-related diseases, in 2004. ${ }^{4}$ The WCA also processed in that year more than 30,000 claims for compensation from illness or injuries acquired on the job. Data from the Australian National Occupational Health and Safety Commission (NOHSC) estimates that a minimum of \$8.5 billion dollars annually is lost to the Victorian economy as a result of workplace injuries and illness ${ }^{5}$-and this figure does not take into account the cost of pain, suffering and early death and its negative impact on families, workplaces and communities. Throughout the country, 5\% of persons employed during the year 2000 experienced work-related injuries and illnesses during that same year. ${ }^{6}$ The purpose of occupational health and safety legislation is to reduce or eliminate such health risks, injury, and death from occupational activity.

This note will provide a concise overview of the Victoria's new Occupational Health and Safety Act 2004. The note will first briefly outline the Maxwell Report on which much of the new OHSA 2004 is based. Then it will examine the principal legislative provisions of the OHSA 2004, concentrating on those which differ from the OHSA 1985 as amended. Finally, the paper will consider what the OHSA 2004 may mean for safety and health in the Victorian workplace. The paper concludes that, although numerous, most changes in the OHSA 2004 comprise relatively small steps from the 1985 Act and are unlikely to usher in a brave new world of occupational health and safety regulation in Victoria.

\footnotetext{
${ }^{2}$ See Occupational Health and Safety Act 2004, s 28 and Part IV (Vic).

${ }^{3}$ Chris MaXwell, Occupational Health AND Safety ACT Review (March 2004) (hereinafter “MAXWELL REPORT”) (available at < $<$ www.dtf.vic.gov.au>).

${ }^{4}$ Victorian WORKCOVER AUthority, WORKING TOGETHER FOR SAFER, HEALTHIER WORKPLACES: FACTS AND FIGURES (available at

$<$ http://www.workcover.vic.gov.au/vwa/home.nsf/pages/ohsact/\$file/factsandfigures.pdf $>$ ) (accessed 15 February 2005).

${ }^{5}$ Id.

${ }^{6}$ Australian Bureau of Statistics, Work-Related Injuries Australia, Pub No 6324.0 (Sept 2000).
} 


\section{THE MAXWELL REPORT}

The Maxwell Report was based on extensive consultations with stakeholders and the community which led to the production of a discussion paper in October 2003. ${ }^{7}$ Submissions on the discussion paper were then taken prior to preparation of the final report in early 2004. The Report focussed on the changing nature of the workforce and of contemporary working arrangements as the catalysts for updating the Occupational Health and Safety Act 1985.

The Maxwell Report found the "legislative framework" of the Occupational Health and Safety Act 1985 to be "structurally sound." ${ }^{8}$ Thus, Maxwell's recommendations were largely consistent with the influential English Robens Report and its broad, general duties on persons with potential to control risks, ${ }^{9}$ rather than the "systems-standard" regulation currently favoured by many commentators. ${ }^{10}$ Systems-standard regulation depends for its enforcement on employers as the primary locus of risk control and emphasises the development, monitoring, and evaluation of systems to control risks. For example, systems-standard regulation might have formulated a duty on employers to identify workplace hazards, assess risks, and develop mechanisms to control those risks. Although retaining the structure of the 1985 Act, the Maxwell Report recommended numerous changes which were determined to make the legislation work better. Broadly, the Maxwell Report called for increased transparency, accountability, and representation in the occupational health and safety regulatory regime.

To accomplish these aims, it recommended the following specific changes to Victorian occupational health and safety law:

- Clarification of coverage of emerging "psycho-social” occupational health risks, such as stress and bullying;

- Greater input into the operation of the WorkCover Authority by stakeholders;

- Moving statements of the WCA's powers in relation to occupational health and safety into the OHSA rather than the ACA;

- Inclusion of a statement of "principles of workplace safety" to add interpretive guidance;

\footnotetext{
${ }^{7}$ MAXWELL REPORT, supra note 3, 16.

${ }^{8}$ Id., at 6 .

${ }^{9}$ REPORT OF THE COMmitTEe ON SAFETy AND HeAlth AT WORK 1970-72, HMSO, London (1972) (Robens Report).

${ }^{10}$ See eg, Liz Bluff, Neil GUnNingham, AND Richard Johnstone (eds), OHS REgULATION FOR A CHANGING WORLD OF WORK (2004); NEIL GUNNINGHAM AND RiCHARD JOHNSTONE, REDESIGNING Occupational Health and Safety Regulation (1998); Neil Gunningham, From Compliance to Best Practice in OHS: The Roles of Specification, Performance and Systems-based Standards, 1996 AJLL LEXIS 25 (1996). As Gunningham has noted, such regulation is perhaps most effective when used for specific hazards or processes and in conjunction with other methods. The downside to such "systems-based" standards is perhaps a tendency to lead to regulation by "box-ticking" rather than effective occupational risk reduction.
} 
- Coverage for new work relationships where control over risks overlaps;

- Duties for all persons in a position to eliminate or control occupational risks, (including new or expanded "upstream" safety duties for designers);

- Alteration of the test of "practicability" which defines the scope of an employer's duty to control or eliminate risks to what is "reasonably practical" and clarification of that standard;

- Requiring employers to take measures to control risk unless the cost of doing so is "grossly disproportionate" to the risk (determined objectively);

- Obligating company officers to take reasonable care to prevent health and safety risks and providing a separate offence for wilful or reckless disregard of risks;

- Insertion of a power for WorkSafe inspectors to provide guidance or advice on compliance with the Act;

- Publishing by the Authority of "safety rulings" on how it interprets the legislation to apply in different factual situations;

- Increasing mechanisms for employee consultation and representation and a concurrent duty on employers to consult;

- Expanding/clarifying that coverage and rights to participate extend to "workers," rather than to employees;

- Provision of limited rights of entry for OHS qualified union officials;

- Eliminating the concept of electing Health and Safety Representatives (HSRs) through "designated work groups" in favour of roving or regional representatives;

- Addition of anti-discrimination protections for HSRs;

- Introduction of a system of incentives and rewards for OHS compliance;

- Clarification of the powers of inspectors, including providing an express power to preserve the scene of an incident for investigative purposes;

- Re-structuring of the enforcement tool of notices;

- Providing the power to accept an enforceable written undertaking from a potential defendant in lieu of prosecution;

- "Substantially increasing" maximum monetary penalties for breaches; ${ }^{11}$

- Providing wider sentencing tools, including custodial sentences for first-time offenders in the case of "high-level culpability", health and safety undertakings, adverse publicity orders, and community service;

- Providing for statutory time limits for the commencement of prosecutions; and

\footnotetext{
${ }^{11}$ The report declined to speculate on a specific figure, deeming that a determination best left to the Government. MAXWELL REPORT, supra note 3, 14.
} 
- Clarification that the Crown is not immune from prosecution for OHS offences.

The Maxwell Report specifically rejected the notion of an offence of corporate manslaughter as inconsistent with the purpose of occupational health and safety law, which is premised on risk identification, reduction and elimination rather than any harm (or death) which may result. It further rejected provisions, such as are contained in the New South Wales Occupational Health and Safety Act 2000, which permit a union to prosecute for breaches of occupational health. The Report also rejected the New South Wales and Queensland positions which place the burden of proof on a defendant employer to raise a defence that desired safety precautions were not "reasonably practicable" in the circumstances, preferring to retain the entire burden of proof of offences on the government. Finally, the Report rejected the establishment of legislative sentencing guidelines in favour of guidelines which may be created through the Court of Appeal.

Although the Maxwell Report did not advocate sweeping change, it did recommend a new focus on participation and, importantly, worker protection through a series of linked strategies. The Report presented Parliament with an opportunity to create a comprehensive scheme towards those ends.

\section{THE OHSA 2004}

The OHSA 2004 is explicitly based on the Maxwell Report, although not all of its recommendations were implemented. ${ }^{12}$ As Rosen has noted, although the Maxwell Report did not recommend "wholesale change or radical surgery", the OHSA 2004 proved controversial in Parliamentary debate and the popular press. ${ }^{13}$ The substantially increased size of the OHSA 2004 and its limited time allotted for debate caused concern, but the chief focus of controversy was the right of union entry into workplaces for suspected OHS violations. The Government moved numerous (45) amendments to the OHSA 2004, although they did not address the opposition's principal concerns with the union right of entry. This section of the note will detail the principal provisions of the OHSA 2004, grouped by their major focus. Where the OHSA 2004 differs from the 1985 Act, those differences will be highlighted.

\footnotetext{
${ }^{12}$ See Victoria, Parliamentary Debates, Legislative Assembly (18 November 2004) 1759 (Hulls, Minister for WorkCover).

${ }^{13}$ Peter Rozen, Significant Change or Merely Fine-Tuning? The Occupational Health and Safety Act 2004 (Vic), 18 AUSTRALIAN J. LABOUR LAW 79, 79 (2005); see also, eg VictORIA, PARLIAMENTARY DEBATES, Legislative Assembly (18 November 2004), 1765-1768 (Doyle, opposition leader, and Ryan, National leader).
} 


\section{A Increased Transparency and Accountability}

Several new provisions of the OHSA 2004 are designed to increase transparency or accountability under the Act. The objects of the OHSA 2004 are slightly expanded to

- $\quad$ secure the health, safety and welfare of employees and other persons at work.

- eliminate at the source, risks to health, safety or welfare of employees and other persons at work,

- $\quad$ ensure that the health and safety of members of the public is not placed at risk by the conduct of undertakings by employers and self-employed persons, and

- $\quad$ provide for the involvement of employees, employers and organisations representing those persons in the formulation and implementation of health, safety and welfare standards. ${ }^{14}$

The objects are to be considered and the legislation is to be interpreted with respect to new "principles of health and safety protection" contained in section 4. A statement of principles was recommended for inclusion by the Maxwell Report, based on those contained in the Environmental Protection Act 1970 (Vic) (EPA), which provide guidance about the purpose of that act. Maxwell recommended principles for occupational health and safety mirroring the language of the EPA that the "aspirations of the people of Victoria for workplace health and safety should drive improvements in the protection of persons at work against risks to health or safety, and in the securing of a safe and healthy work environment", along with the "precautionary principle," "principle of enforcement" and the "principle of shared responsibility". ${ }^{15}$

Maxwell also recommended the inclusion of other principles with a more specific OHS focus, including

the principle of paramountcy, that is, the principle that if an activity cannot be carried on safely, it should not be carried on at all; the principle of consultation, representation and participation; the principle of elimination of risk at source; and the principle of systematic management of risk in the workplace. $^{16}$

The suggested principles in the Maxwell Report would indeed provide interpretive guidance, because they set priorities and goals which courts could use to expand on the intended outcomes of general duty provisions.

However, the principles actually contained in the OHSA 2004 differ significantly from those recommended in the Maxwell Report. The OHSA 2004 principles

\footnotetext{
${ }^{14}$ Occupational Health and Safety Act 2004 (OHSA 2004), sec 2(1) (Vic).

${ }^{15}$ MAXWELl REPORT, supra note 3, paras 39-47.

${ }^{16} I d .$, , at para 45 .
} 
include that persons at work are entitled to the highest level of protection against risks to their health and safety that is reasonably practicable in the circumstances; persons who control or manage workplaces are responsible for eliminating or reducing risks as far as is reasonably practicable; employers and self-employed persons should be proactive in ensuring health and safety so far as practicable; employers and employees should "exchange information" about reducing risks; and employees have the right to representation in health and safety matters. ${ }^{17}$ The OHSA 2004 statement of principles as enacted are unlikely to provide interpretive guidance for the regulator, courts, or stakeholders when confronting the general duties contained in the OHSA 2004. They largely re-state obligations contained in the general duty provisions and water down both employee rights to participation and employee responsibility for the control of OHS risks.

Although the chief duties for employers and others remain the same under the 1985 Act and OHSA 2004, the standard is expressed differently. The 1985 Act required employers to eliminate risks "so far as is practicable", having regard to certain enumerated factors. The OHSA 2004 provides that the employer's duty is to "eliminate or reduce" risks as far as is "reasonably practicable." ${ }^{18}$ It is questionable what value the language change from "practicable" to "reasonably practicable" will have. The notion of practicability already made the standard in the 1985 Act effectively one of negligence, and the addition of "reasonableness" to the standard seems to provide little alteration in the actual standard or assistance towards clarity in compliance. ${ }^{19}$ Although this alteration in the expression of the standard was recommended in the Maxwell Report, the legislation does not implement the closely related recommendation to require the reduction or elimination of risks unless the cost is "grossly disproportionate" to the risk. This omission ignores key findings of the Maxwell Report, namely that costs dominated other considerations of compliance under the 1985 Act and that parties required greater guidance in assessing cost factors relative to risks. ${ }^{20}$

The general standard of "reasonably practicable" is made more specific through a list of factors required to be considered (although the legislation does not specify that the following is a closed list):

- The likelihood of the hazard eventuating

- The degree of harm that would result

- What the person knows or ought reasonably to know about the hazard and ways of reducing it

- The availability and suitability of ways to eliminate or reduce the risk

\footnotetext{
${ }^{17}$ Occupational Health and Safety Act 2004, sec 4, (Vic).

${ }^{18}$ Occupational Health and Safety Act 2004, ss 20 \& 21 (Vic).

${ }^{19}$ See, eg, Adrian Brooks, Risk Management and Consultation Systems: Developments and Disappointments in the New Occupational Health and Safety Legislation in New South Wales, 24 SYDNEY L. REV. 89, 99 (2002).

${ }^{20}$ See MAXWELL REPORT, chapter 12 and infra, section IV.
} 
- The cost of eliminating or reducing the risk. ${ }^{21}$

This list covers essentially the same factors as the definition of "practicable" in the 1985 Act, $^{22}$ in a slightly different formulation. The different language could indeed generate different outcomes if courts are sensitive to the language changes. It is at present difficult to say whether prior precedent interpreting practicability will, as a practical matter, override the weight placed on legislative expression.

The OHSA 2004 retains the obligation that employers' occupational health and safety duties extend to workers other than employees at common law, such as contractors and their employees. ${ }^{23}$ The Victorian statue already extended an employer's duties farther than other those of other states with regard to public health risks generated by an enterprise, ${ }^{24}$ and that standard has also been preserved in the new legislation. ${ }^{25}$ Public health has been given an even more prominent focus through its inclusion in the objects section of the OHSA 2004. ${ }^{26}$ This is a positive change.

Additionally, the OHSA 2004 clarifies the liability of bodies corporate or their officers. Acts of employees, agents or officers acting within the actual or apparent scope of their authority are deemed to be acts of the corporation for purposes of determining corporate liability under the Act. ${ }^{27}$ In a new offence, an "officer" of a corporation (including the government) can be separately liable for occupational health and safety violations. ${ }^{28}$ Section 144 provides that if a corporation breaches a provision of the OHSA 2004 and the breach is attributable to "an officer of the body corporate failing to take reasonable care," having regard to enumerated factors including the extent to which the officer can make decisions in the area concerned, the officer can be liable as a natural person. An "officer" is defined as one who makes or participates in making decisions affecting the whole or a substantial part of the corporation's business and has the capacity to significantly affect the finances of the corporation, and specifically excludes those acting in a voluntary capacity. ${ }^{29}$ This new duty has increased officer liability significantly as compared to that contained in the 1985 Act. In fact it is drafted in a broader fashion than

\footnotetext{
${ }^{21}$ Occupational Health and Safety Act 2004, s 20(2) (Vic).

${ }^{22}$ Compare Occupational Health and Safety Act 1985, sec 4 (Vic).

${ }^{23}$ Occupational Health and Safety Act 2004, ss 21(3) \& 23 (Vic). Recognition of the variety and complexity of contemporary work arrangements which may give rise to health risks is an important component of the design of any effective occupational health system. See, eg, Richard Johnstone, Paradigm Crossed? The Statutory Occupational Health and Safety Obligations of the Business Undertaking, 1999 AJLL LEXIS 8 (1999); Michael Quinlan, The Implications of Labour Market Restructuring in Industrialised Countries for Occupational Health and Safety, University of New South Wales School of Industrial Relations and Organisational Behaviour Working Paper No 116 (1997).

${ }^{24}$ Richard Johnstone, The Legal Concept of Work-Related Injury and Disease in Australian OHS and Workers’ Compensation Systems, 2002 AJLL LEXIS 3 (2002).

${ }^{25}$ Occupational Health and Safety Act 2004, sec 23 (Vic).

${ }^{26}$ Occupational Health and Safety Act 2004, sec 2(1)(c) (Vic)

${ }^{27}$ Occupational Health and Safety Act 2004, sec 143 (Vic).

${ }^{28}$ Occupational Health and Safety Act 2004, sec 144 (Vic).

${ }^{29}$ Occupational Health and Safety Act 2004, ss 5 and 144(5) (Vic).
} 
recommended in the Maxwell Report, since matters such as control and knowledge of the officer form factors for consideration in liability, not an absolute defence.

Other provisions increase accountability under the Act. Decisions of Authority inspectors are reviewable by WorkSafe, and employers are entitled to a further appeal to VCAT, rather than through the Magistrate's Court. ${ }^{30}$ This new appeal procedure may make available faster decisions, since the recent dramatic increase in the jurisdictional ceiling of the Magistrate's Court is bound to increase its docket. ${ }^{31}$ The OHSA 2004 makes clear that the provisions of the Act apply to the Crown as well as to private employers. ${ }^{32}$ Also, employers should welcome a new section which provides that compliance with regulations or a relevant compliance code conclusively demonstrates compliance with the Act. ${ }^{33}$

\section{B New Powers for the WorkCover Authority and the Government}

The OHSA 2004 provides for some expanded or clarified powers for the WorkCover Authority and relevant governmental officials. These are largely contained within Part 2 of the Act.

New provisions grant the WCA a power to require a person to provide information or produce documents in connection with an investigation of a breach of the Act or regulations. ${ }^{34}$ This power also carries a concurrent obligation on persons to cooperate with WCA inspectors subject to an offence if the provision is not complied with, unless there is "reasonable excuse." This obligation is qualified by a limited privilege against self-incrimination. ${ }^{35}$

The WCA was granted powers which were welcomed by employer groups and the opposition as increasing transparency in the regulatory scheme and facilitating compliance by employers. The Authority is now permitted to provide advice to employers on compliance with the Act and regulations. ${ }^{36}$ The WCA is also granted powers to make guidelines as to occupational health and safety practices. ${ }^{37}$ The legislation appears to anticipate that the guidelines would take a form analogous to advisory opinions on how the Act or regulations would apply to a given set of facts. Any guidelines must be publicly available. However, compliance with the guide-

\footnotetext{
${ }^{30}$ Occupational Health and Safety Act 2004, ss 128 \& 129 (Vic).

${ }^{31}$ Magistrate's Court Act 1989, sec 3 (Vic).

${ }^{32}$ Occupational Health and Safety Act 2004, sec 6 (Vic).

${ }^{33}$ Occupational Health and Safety Act 2004, sec 152 (Vic).

${ }^{34}$ Occupational Health and Safety Act 2004, sec 9 (Vic).

${ }^{35}$ Occupational Health and Safety Act 2004, sec 9(3) (Vic). This limited privilege was added by Government amendment after the second reading of the bill. VICTORIA, PARLIAMENTARY DEBATES, Legislative Assembly (9 December 2004) 2259-2260.

${ }^{36}$ Occupational Health and Safety Act 2004, sec 18 (Vic).

${ }^{37}$ Occupational Health and Safety Act 2004, sec 12 (Vic).
} 
lines or advice does not give rise to any defence under the Act, ${ }^{38}$ which appeared to be a sore point with employers, according to Parliamentary debate.

One of the more unusual new governmental powers is ability of the Minister to delegate "all or any of his or her functions or powers under the Act or Regulations to any person" subject only to Ministerial directions. ${ }^{39}$ The Victorian Scrutiny of Acts and Regulations Committee suggested that this provision was unnecessarily broad. ${ }^{40}$ Indeed the need for or purpose of such an unfettered power remains obscure and was not addressed in debate.

\section{Worker and Stakeholder Input}

One key and rather controversial new duty is the employers' duty to consult with employees on various occupational health issues. ${ }^{41}$ "So far as is reasonably practicable,” employers must consult with employees, independent contractors or their employees when:

- $\quad$ identifying or assessing risks arising from the conduct of the undertaking;

- making decisions about the control of risks or the adequacy of facilities;

- making decisions about procedures for resolving health and safety issues, consulting with employees, monitoring health of employees, providing training and information;

- $\quad$ determining members of a health and safety committee;

- $\quad$ proposing changes that may affect the health and safety of employees; or

- $\quad$ as prescribed by the regulations. ${ }^{42}$

A breach of the duty to consult is a new offence carrying relatively light fines. ${ }^{43}$ "Consultation" consists of sharing relevant information, providing an opportunity to express views, and "taking those views into account." 44 Like the similar provisions in the New South Wales Act on which this appears to be based, the requirement is one of "consultation" (which an employer is free to disregard) rather than an express right to employee "participation" in decision-making. A failure to require active participation, rather than more passive worker involvement through "consultation" has been criticised as failing to empower workers to have real control in OHS decision-making. ${ }^{45}$ A requirement to provide notice and an opportunity to be heard and considered does provide some natural justice. However, where the decision-maker/employer is not a neutral (as in a court) but is an interested party, these minima are not sufficient to enable employees to act as self-regulators. Fur-

\footnotetext{
${ }^{38}$ Occupational Health and Safety Act 2004, sec 15 (Vic).

${ }^{39}$ Occupational Health and Safety Act 2004, sec 156 (Vic).

40 SARC VICTORIA, Occupational Health and Safety Bill, ALERT DigEST No 11 OF 2004.

${ }^{41}$ Occupational Health and Safety Act 2004, ss 35 \& 36 (Vic).

${ }^{42}$ Occupational Health and Safety Act 2004, sec 35 (Vic).

${ }^{43}$ Occupational Health and Safety Act 2004, sec 35(3) (Vic)

${ }^{44}$ Occupational Health and Safety Act 2004, sec 36 (Vic).

${ }^{45}$ See Brooks, supra note 19 , at 121-122.
} 
ther, failing to implement a more participatory scheme may prevent "ownership" of occupational health and safety obligations by front-line employees, thought to be fundamentally important in the reduction of work-related risks.

The concept of health and safety representatives (HSRs) elected from "designated work groups" is retained but made more flexible. ${ }^{46}$ Either employees or employers may seek to establish designated work groups for occupational health and safety purposes by agreement. ${ }^{47}$ The legislation provides that employers and employees may agree on the number of HSRs for each work group, allows for the election of deputy HSRs upon agreement, and clarifies (similar to the position advocated in the Maxwell Report) that one HSR may represent workers at different sites if agreed. ${ }^{48}$ The OHSA 2004 also allows for multiple employers and employees to establish by agreement designated work groups across employers, and for the role of multiemployer HSRs to be recognised by law. ${ }^{49}$ Either an HSR or an employer (following consultation) may give directions to cease work if a health and safety issue arises which involves an immediate threat to health or safety and it is appropriate given the nature of the threat and degree of risk. ${ }^{50}$ Some employers may be required to set up health and safety committees of which half the members must be employees. ${ }^{51}$ Detailed provisions on the establishment of designated work groups, the election of HSRs, and their powers are found in Part 7 of the OHSA 2004.

Clearly the most controversial provision of the OHSA 2004 is the power of entry into workplaces granted to OHS trained and authorised union representatives. ${ }^{52}$ Such representatives have powers of entry for health and safety if they "reasonably suspect" occupational health or safety breaches in a workplace. ${ }^{53}$ This right of entry is subject to strict limitations and penalties for violation. For example, a right of entry requires a permit issued by the Magistrate's Court based upon a specified suspected violation and is only available to OHS trained officers or permanent employees of a registered organisation. A permit holder may be disqualified for "intentionally hindering or obstructing an employer or employee" or "acting unreasonably." ${ }^{54}$ The right of entry requires that the permit holder must take "all reasonable steps" to provide to the employer and any HSR both notice of his or her arrival, and the entry permit with the description of the suspected contravention of the OHSA 2004. ${ }^{55}$ The permit holder may only "to the extent reasonable" inspect, observe, and consult, for purposes of enquiry into the suspected contravention of

\footnotetext{
${ }^{46}$ See Occupational Health and Safety Act 2004, ss 43 and 47 et seq (Vic).

${ }^{47}$ Occupational Health and Safety Act 2004, sec 43 (Vic).

${ }^{48}$ Occupational Health and Safety Act 2004, sec 44 (Vic).

${ }^{49}$ Occupational Health and Safety Act 2004, ss 47-51 (Vic).

${ }^{50}$ Occupational Health and Safety Act 2004, sec 74 (Vic).

${ }^{51}$ Occupational Health and Safety Act 2004, sec 72 (Vic).

${ }^{52}$ See, eg, supra note 11. The Federal government's proposal to enact a national standard for rights of entry could possibly affect these provisions, but a thorough analysis of the impact of such a proposal is beyond the scope of this brief note.

${ }^{53}$ Occupational Health and Safety Act 2004, Part 8, particularly ss 80-90 (Vic).

${ }^{54}$ Occupational Health and Safety Act 2004, sec 85 (Vic).

${ }^{55}$ Occupational Health and Safety Act 2004, sec 88 (Vic).
} 
the OHSA 2004. ${ }^{56}$ Permit holders are subject to offences if they violate the statute and may also be required to make good any loss or damage on the part of the employer. $^{57}$

In an attempt to provide the regulator itself with more input from stakeholders, the OHSA 2004 establishes an Occupational Health and Safety Advisory Committee (OHSAC) for the WorkCover Authority. The OHSAC is a tripartite structure, to be made up of a majority of employer and employee representatives as well as government advisers, all chosen by the responsible Minister. In addition, the Minister is to appoint two "independent" persons knowledgeable on occupational health and safety matters. ${ }^{58}$ This panel is to advise the Authority on occupational health and safety matters and to inquire and report on any matters designated by the Authority.

\section{New Duties and Offences}

Several new or amplified duties and offences have been incorporated into the OHSA 2004, in addition to those already discussed under other subheadings in this note. An employer's duty to guard against risk now expressly covers psychological as well as physical health. ${ }^{59}$ The OHSA 2004 also requires notification to the Authority of incidents involving death or certain serious injuries, along with preservation of a workplace site where an incident resulting in death or serious injury occurred, for the purpose of investigation. ${ }^{60}$

As recommended in the Maxwell Report, the OHSA 2004 expands "upstream” duties on parties other than employers who exert control over workplaces and work systems. While some of these parties also had obligations under the 1985 Act (suppliers and manufacturers), ${ }^{61}$ newly added are duties for designers of plant and buildings or structures to be used as workplaces.

A new duty for those who have "to any extent the management or control of a workplace” covers areas over which the person has management or control and requires the person to ensure "so far as is reasonably practical that the workplace and the means of entering it and leaving at are safe and without risks to health." ${ }^{2}$ This duty is largely overlapping with an employer's general duty but certainly has the potential to cast a broader net by including managers. Designers of plant who "ought reasonably to know that the plant is to be used as a workplace," must ensure, to a "reasonably practicable" standard that the plant is without risks to health, carry out testing necessary to ensure the general duty, and provide such information on the plant to those to whom the design is given. ${ }^{63}$ The 2004 statements of supplier

\footnotetext{
${ }^{56}$ Occupational Health and Safety Act 2004, sec 89 (Vic).

${ }^{57}$ Occupational Health and Safety Act 2004, ss 91 \& 92 (Vic).

${ }^{58}$ Occupational Health and Safety Act 2004, sec 19 (Vic).

${ }^{59}$ Occupational Health and Safety Act 2004, sec 5 (Vic).

${ }^{60}$ Occupational Health and Safety Act 2004, ss 38 \& 39 (Vic).

${ }^{61}$ See Occupational Health and Safety Act 1985, ss 23-24 (Vic).

${ }^{62}$ Occupational Health and Safety Act 2004, sec 26 (Vic).

${ }^{63}$ Occupational Health and Safety Act 2004, sec 27 (Vic).
} 
and manufacturer duties are comparable and also provide for the new standard of "reasonable practicability." ${ }_{44}$ A similar general duty is placed on designers of buildings or structures to be used as workplaces. ${ }^{65}$ These provisions are consistent with the National OHS Strategy 2002 - 2012, which contains a commitment "to eliminate hazards at the design stage." ${ }_{66}$

Finally, a general duty is placed on a person who

installs, erects, or commissions plant . . . who ought reasonably to know that the plant is to be used as a workplace must ensure, so far as is reasonably practicable, that nothing about the way the plant is installed, erected or commissioned makes its use unsafe or a risk to health. ${ }^{67}$

As a large percentage of buildings, plant or structures (including residences) may be someone's workplace, such duties could prove a significant extension of occupational health and safety liability if such provisions are enforced by expanding the set of persons to whom one would owe duties. This expansion would presumably be tort-like-towards persons affected, rather than spring from contractual relations like employees or contractors. For example, under this section residential builders could be responsible not only for the safety of their crews but for "sick building syndrome" developed by workers using a home office.

Similar to the new statement of general employer duties in section 21(1), the duty placed on self-employed persons is amended to require them to ensure so far as "reasonably practicable" that persons are not exposed to health or safety risks "arising from the conduct of the undertaking" of the self-employed person. ${ }^{68}$ Section 25 retains the duty on employees to take reasonable care for their own health and safety, as well as the health and safety of others who may be affected by the employees' acts and omissions.

A new indictable offence is created for persons who "without lawful excuse recklessly engage in conduct that places or may place a person at a workplace in danger of serious injury." ${ }^{9}$ This section carries heavy penalties, including the possibility of imprisonment for up to five years. Largely because of the stiff penalties, this section was quite controversial in Parliamentary debate. What constitutes "recklessness" is undefined, but will both draw upon and be informed by court decisions. It is early days yet to speculate on the type of conduct that might constitute recklessness; however, recklessness has been determined in other contexts to require some awareness of a present risk and deliberate disregard of that risk.

\footnotetext{
${ }^{64}$ Occupational Health and Safety Act 2004, ss 29 \& 30 (Vic).

${ }^{65}$ Occupational Health and Safety Act 2004, sec 28 (Vic).

${ }^{66}$ MAXWELL REPORT, supra note 3, para 796.

${ }^{67}$ Occupational Health and Safety Act 2004, sec 31(Vic).

${ }^{68}$ Occupational Health and Safety Act 2004, sec 24 (Vic).

${ }^{69}$ Occupational Health and Safety Act 2004, sec 32 (Vic).
} 
Finally, there are new indictable offences relating to discrimination against health and safety representatives (HSRs). ${ }^{70}$ The prohibition is structured similarly to the Freedom of Association provisions in the Commonwealth Workplace Relations Act $1996,{ }^{71}$ which prohibit an employer from firing, refusing to hire, or otherwise injuring an employee to his or her detriment because of the employee's act as an HSR or assistance to an HSR. If all facts constituting an offence of discrimination are proved, the onus of proof shifts to the defendant to show (in effect an affirmative defence) that the prohibited reason was not the "dominant reason" for the less favourable treatment. ${ }^{72}$ Violations of the antidiscrimination provision can give rise to an indictable offence (including imprisonment), as well as orders for reinstatement or damages. ${ }^{73}$

\section{E New Penalties /Sentencing Abilities}

An important change from the 1985 Act is increased penalties for violations of the Act. ${ }^{74}$ Penalties under the OHSA 2004 have been increased to $\$ 102.25$ per penalty unit. The former mandatory minimum penalties have been removed, so some penalties increased and some have actually reduced. ${ }^{75}$ The maximum penalty for a breach of general duties is now $\$ 920,250$ for a corporation or $\$ 184,050$ for an individual.

One surprising omission from the OHSA 2004 is a counterpart to the former section 53 of the 1985 Act, which provided for increased penalties for subsequent related offences. Section 53 (1985 Act) was used to increase applicable penalties, for example, in the Esso case, where an employer had a record of prior violations for the same type of offence. ${ }^{76}$ Given that one deficiency Maxwell identified in the 1985 Act was its low penalty provisions relative to that of other states, it is curious that it is no longer possible to take into account the historical record of occupational health and safety compliance for sentencing purposes, at least as a matter of specific deterrence for repeat offences of a similar nature-ie, learning from one's past mistakes. ${ }^{77}$ This omission is significant enough to warrant correction by amendment.

\footnotetext{
${ }^{70}$ Occupational Health and Safety Act 2004, sec 76 (Vic).

${ }^{71}$ See Workplace Relations Act 1996, ss 298K and 298L (Cth).

${ }^{72}$ Occupational Health and Safety Act 2004, ss 76(3) \& 77 (Vic).

${ }^{73}$ Occupational Health and Safety Act 2004, ss 76(4) \& 78 (Vic)

${ }^{74}$ See, eg, Occupational Health and Safety Act 2004, sec 21 (Vic).

${ }^{75}$ WorkSafe Victoria, OcCupational Health AND SAFETy ACt 2004: AN Overview 4 (2005) (available at < $<w w$.worksafe.vic.gov.au>) (accessed 10/03/2005).

${ }^{76}$ DPP v Esso Australia Pty Ltd [2001] VSC 263 (Sup Ct Vic 30 July 2001). For commentary, see Karen Wheelwright, Corporate Liability for Workplace Deaths and Injuries - a Critique of Current and Proposed Legal Models in the Light of the Esso Longford Explosion, 7 DEAKIN L. REV. 323 (2002).

${ }^{77}$ But see Neil Gunningham, Towards Innovative Occupational Health and Safety Regulation, $40 \mathrm{~J}$. INDUSTRIAL RELATIONS 204, 209 (1998) (finding empirical research to show that specific deterrence does not require large fines or penalties, although general deterrence does benefit from larger penalties).
} 
There are also new provisions for additional sentencing abilities beyond monetary fines, like adverse publicity orders or community improvement projects. ${ }^{78}$ The OHSA 2004 also provides for the enforceability of written undertakings by an employer for matters relating to contraventions (or alleged contraventions) of the Act or regulations. ${ }^{79}$ These undertakings may be made in lieu of fine or imprisonment. The court, in addition, may require an employer offering an undertaking to submit to a health and safety audit, hire a consultant, or develop a risk management system. ${ }^{80}$ Finally, the Authority now has a limitation period of two years from the date of an offence for charging an indictable offence, although the Director of Public Prosecutions (DPP) may override this limitation. ${ }^{81}$

\section{COMMENTARY}

The Occupational Health and Safety Act 2004 is rather a mixed lot. While there are some important new provisions and duties, as a package the substantive changes in the OHSA 2004 as compared to the 1985 Act are relatively slight, and certainly not the radical and oppressive regime that was suggested in Parliamentary debate. As noted above, few, if any, parts of the OHSA 2004 appear to implement measures of so-called "systems-standard" regulation. The basic structure and general duties placed on major stakeholders remain the same as in the 1985 Act. This is perhaps understandable, given that such was the aim and intention of the Maxwell Report upon which the OHSA 2004 is based.

Positive developments include that interpretive provisions are substantially increased, which may assist the stakeholders and the courts to clarify obligations under the Act. The retention and intensification of a focus on public health in the objects of the Act keeps Victoria a leader in Australia in recognising the public health risks of occupational activity, but more could be done in this area through more specific measures. Also, the anti-discrimination provisions protecting health and safety representatives are an appropriate protection for workers engaging in a sometimes thorny obligation.

Other welcome developments are the powers of the WCA to provide advice and make guidelines, the absence of which has severely hampered the transparency of employers' obligations and the regulatory effectiveness of the WCA. The increase in penalties, although controversial in debate, merely brought Victoria in line with other states where it had fallen considerably behind. The inclusion of creative sentencing options should lead to more incentives for compliance.

Increased flexibility in the election of recognised health and safety representatives (HSRs) is another beneficial development. The flexibility allows for health and

\footnotetext{
${ }^{78}$ Occupational Health and Safety Act 2004, ss 135-136 (Vic).

${ }^{79}$ Occupational Health and Safety Act 2004, ss 137 \& 16 (Vic).

${ }^{80}$ Occupational Health and Safety Act 2004, sec 137(3) (Vic).

${ }^{81}$ Occupational Health and Safety Act 2004, sec 132 (Vic).
} 
safety representation to be tailored to a particular workplace (or workplaces) in ways that make sense for the operation of the enterprise. However, as these moves are all subject to agreement, it remains to be seen whether the provisions are put to use. The highly controversial union powers of entry are comparatively limited and, particularly when coupled with an employer's right to damages, unlikely to generate large-scale problems as suggested in Parliamentary debate. Moreover, studies have shown that union representation is crucial to the effective implementation of employee participation in occupational health and safety regimes. ${ }^{82}$

With regard to the changes in the principal general duty of employers in s. 21, the addition of a clear duty to reduce risks where it may not be practicable to eliminate them is a positive change. However, the connotation of the redundant-sounding "reasonably practicable" standard may lead to an undue emphasis on costssomething Maxwell was keen to avoid. The Maxwell Report criticised the past lack of an explicit and consistent cost-benefit methodology in the legislation. He suggested that there should be a recognised "transparent bias" in favour of health and safety. ${ }^{83}$ However in the OHSA 2004, s. 20 clarifies "the concept of health and safety" by enumerating considerations of "reasonable practicability" "to avoid doubt." Under that section, two of five factors enumerated relate to costs. ${ }^{84}$ There is no suggestion that prevention or risks to health should trump expenditure nor even that a "tie" of costs and benefits should be weighed in favour of risk prevention.

Given the recommendation in the Maxwell Report to create a concurrent obligation to reduce risk unless the cost of doing so is "grossly disproportionate," the bare standard of "reasonable practicability” is a significant disappointment. The Maxwell Report recommended that

the cost factor in "practicability" be clarified, to make clear that duty holders are obliged to take risk prevention measures unless the cost of a preventative measure would be "grossly disproportionate" to the risk as assessed. The Act should also be amended to state explicitly what it already says implicitly, that the content of the safety duties in a workplace does not depend upon the particular financial circumstances of the duty holder. ${ }^{85}$

The employer's duties as expressed in section 21 do not approach the protective standard recommended by Maxwell. In any case, the standard to be complied with is certainly not raised by the change to "reasonable practicability" and may even be lowered under this formulation, since it lacks a clear counterbalance to cost considerations. The Maxwell Report's recommendation should be implemented.

\footnotetext{
${ }^{82}$ See, eg, David Walters, Workplace Arrangements for Worker Participation in OHS in OHS REGULATION FOR A CHANGING WORLD OF WORK 68, 75-77 (Liz Bluff, Neil Gunningham, and Richard Johnstone, eds., 2004).

${ }^{83}$ MAXWELl RePORT, supra note 3, paras 510-567.

${ }^{84}$ Compare Occupational Health and Safety Act 2004, ss 20(d) \& (e) (Vic).

${ }^{85}$ MAXWELL REPORT, supra note 3, paras 504-505.
} 
Some other glaring omissions from the OHSA 2004 warrant re-consideration. For example, the lack of an analogue to the 1985 Act's s. 53 remains a curious omission. Further, where an employer has complied with public guidelines on specific issues or sought, received and complied with advice from the WCA, it does seem unreasonable not to provide an affirmative defence carrying at least reduced penalties under the OHSA 2004. Such a move would increase employers' incentives to seek advice from the WCA on particular matters and may improve compliance.

It remains to be seen whether the WCA takes its expanded powers and develops into a more pro-active regulator. Further, it is unclear whether the procedural changes to review of decisions brought in by the Act will result in different outcomes.

Overall, the Occupational Health and Safety Act 2004 inches towards the $21^{\text {st }}$ Century in some ways but fails to deliver a robust new occupational health and safety regime in Victoria, as envisioned in the Maxwell Report. Enacting only portions of the Maxwell Report in the OHSA 2004 dilutes its recommended scheme into much less than was anticipated. In fact, omitting or altering key recommendations on "principles of health and safety" and employer duties has created an Act that is in some ways more regressive than progressive. Although the OHSA 2004 is significantly longer and more complex than its predecessor, it has disappointingly failed to deliver on the promises of safety and participation in the Maxwell Report. 